\title{
The Application of Diagnostic Plots to Evaluate Water Flooding
}

\author{
Ratna Widyaningsih ${ }^{1 *)}$, Muhamad Zamzam Istimaqom ${ }^{1)}$, Hizballah Nidaulhaq ${ }^{1)}$, Atma Budi Arta ${ }^{1)}$ \\ 1) Petroleum Engineering Department, UPN “Veteran” Yogyakarta \\ *) Email: ratna.widyaningsih@upnyk.ac.id
}

\begin{abstract}
To analyze production optimization using waterflood, several types of diagnostic plots are needed to determine the response to using waterflood. If you have analyzed 1 plot, it is necessary to conduct a comprehensive analysis to evaluate its success rate by combining it using another plot analysis. The X-Min Field is a field that produces light oil and is managed by the Asset Optimization SLO North PT. Chevron Pacific Indonesia. This field was discovered in 1959 and started to be produced in 1966. Currently, 100 wells have been drilled with 37 active wells from 43 production wells, active injector wells are 18 out of 19, inactive wells 30, 4 wells have been plugged in, and there are 4 active wells that produce gas. The number of OOIPs in this field is 593 MMBO with cumulative production reaching 283.7 MMBO and Recovery Factor reaching 47.7\%. In 2017 it was noted that the current production in December 2017 amounted to 5,374 BOPD / 121,264 BFPD or in other words the water cut reached 96.6\%. Meanwhile, the amount of injection used to optimize this field is 144,103 BWIPD. Reservoirs in this field have 4 reservoirs namely Res-1, Res-2, Res-3, and Res-4 wherein each reservoir there are several grains of sand optimized using waterflood. There was 8 sand analyzed, including Sand Asyique, Sand Bajubaru, Sand Cemangad, Sand Emakpintar, Sand Fantamantap, Sand Gulungulung, Sand Harikita, and Special Sand. Closes the producer indicated premature water breakthrough. General recommendations given to various sands include adding or subtracting, both injectors and producers based on the response of each sand to water flooding.
\end{abstract}

Keywords: Waterflooding, Producer, Injector, Respond Waterflood

\section{INTRODUCTION}

Waterflood is the process of injecting water into a reservoir to obtain oil that is still trapped in the pores of rocks after passing the primary recovery limit. Water is injected from the injector well then water moves through the reservoir rock pores so that the water forces oil to flow into the production well. It is expected that water moves always behind the front and oil moves in front of the front so that more oil is obtained before the breakthrough occurs. When a breakthrough occurs when injection water enters the production well, the water production will increase rapidly.

The use of waterflood is used has 2 functions, namely as pressure maintenance and improve efficiency. In the pressure maintenance function, this needs to be done so that no gas comes out of the well and can damage the pump and other facilities. Reservoir pressure will tend to decrease due to the production of oil to the surface during primary recovery. Meanwhile, the function as water that is injected will replace oil trapped in the pores of reservoir rocks and oil will be pushed up to the surface. This can reduce residual oil saturation so that the oil produced will be more.

After doing water flooding, evaluation is needed to find out whether water flooding is successful or not. For this reason, diagnostic plots are needed to determine further recommendations.

\section{TYPES OF PLOT DIAGNOSTICS}

To analyze production optimization using waterflood, several types of diagnostic plots are needed to determine the response to using waterflood. If you have analyzed 1 plot, it is necessary to conduct a comprehensive analysis to evaluate its success rate by combining it using another plot analysis. As for this paper, there are 4 diagnostic plots used to analyze data from sand, as follows. 


\subsection{Maturity Plot (Rf vs PVI)}

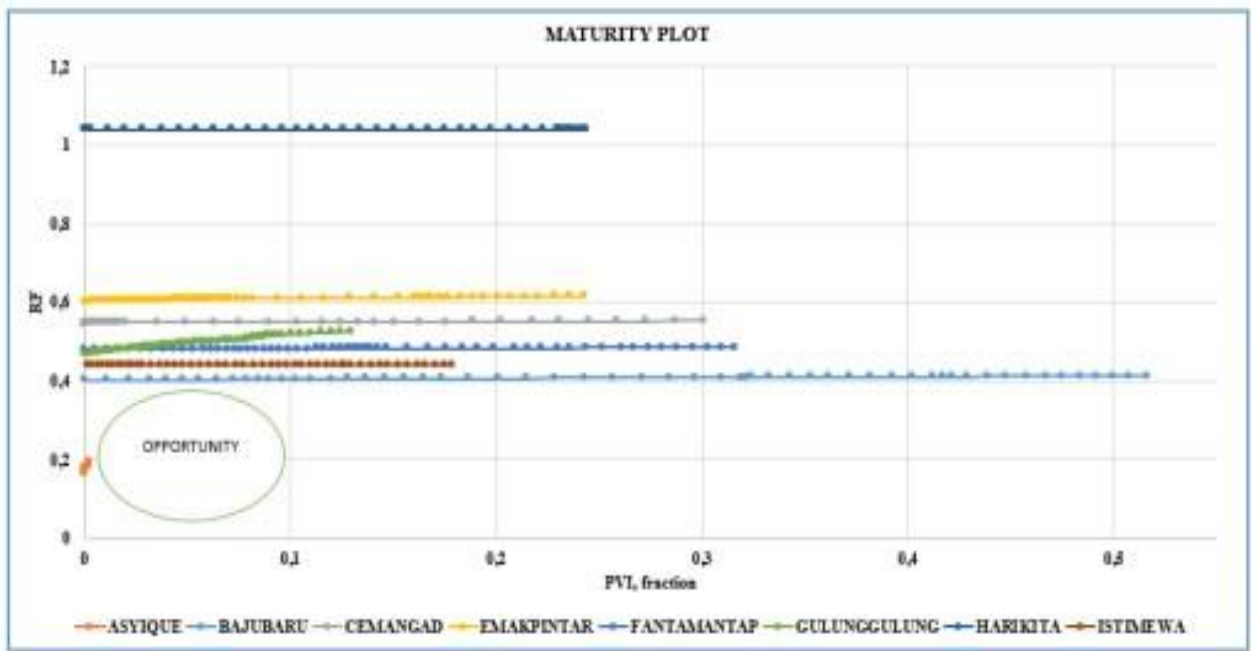

Graph 1. Maturity Plot (Rf vs PVI)

A maturity plot is a plot used to see the addition of recovery factor when adding injection to pore volume (PVI). The best response is seen from the response to the increase in RF to bwipd water injection. In addition, from graph 1.1. shows the ratio of each RF between one sand with another sand. The RF trend line with the highest increase is the most optimal sand. Meanwhile, the sand which is still in the early stages of development has a very small RF. Thus, this sand is an opportunity as well as a challenge to improve performance to increase production. In this plot, the best response is shown in Sand Gulung-gulung where the addition of Pore Volume Injected (PVI) shows a good increase in RF. Meanwhile, the sand that needs to be optimized is Sand Asyique because the recovery factor has only reached 0.175 . However, it is very likely that Sand-Ashyique can still be produced primarily.

The amount of RF of sand has a maximum value of 1.00 , so if the RF calculation has a value of $>1$, then there is a possibility of an error in determining the allocation of factors. The thing that might happen is that there is a cross-flow unit that is caused by wells that are produced by coming. In this case, there is an error in SandHarikita where the RF data obtained has a value greater than 1 (one).

\subsection{WOR vs Cumulative Oil}

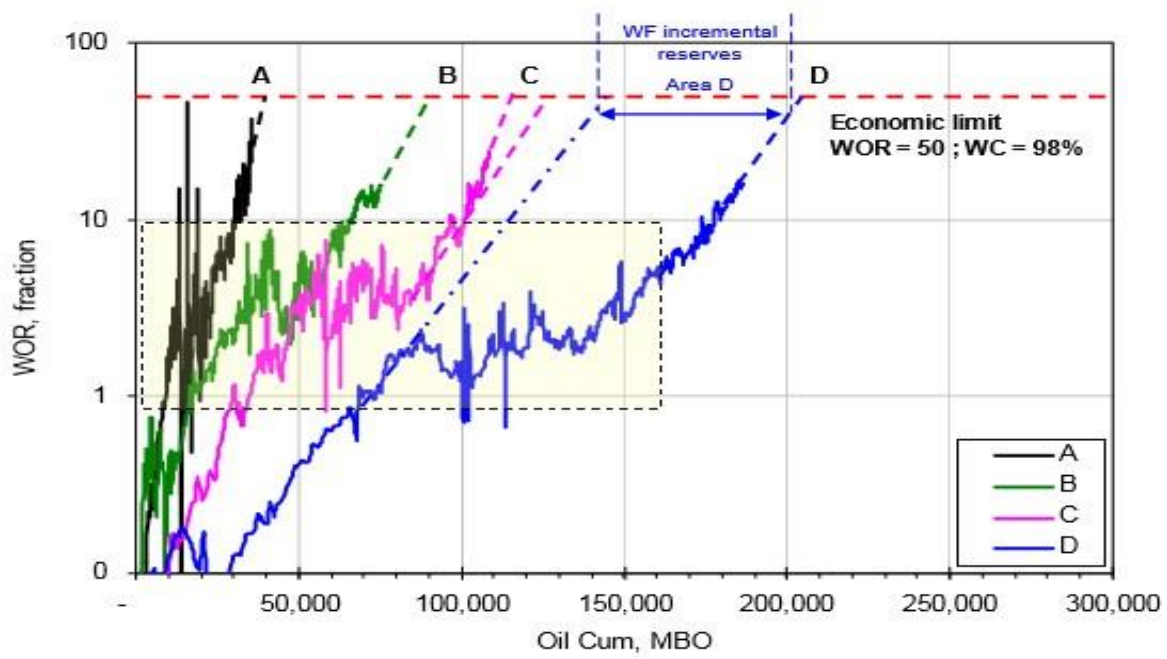

Graph 2. WOR vs Cum. Oil

The response of waterflood to the increase in WOR seen from the trend fluctuation. By breaking the trend line, it can be concluded that the amount of reserve that can be taken will be even greater. 
From the areas of graph B, C and D show a good response to waterflood where area D shows a significant increase in production of around 50 MMSTB.

Area A has a poor response to waterflood with WOR rapidly increasing. This problem could have been caused by premature water breakthrough via high perm streak (thief zone), fracture, or poor waterflood management.

Area $\mathrm{C}$ actually has a good response to waterflood but then WOR rises faster. Then this is an opportunity to reduce water cycling in the area to reduce WOR.

This method has the following limitations:

- This method can only be used for mature water floods where the water cut is at least $75 \%$

- This plot is not effective if $\mathrm{Kv} / \mathrm{Kh}>1$

- This method can only be used when doing waterflood in more than one zone where the permeability difference is more than $4: 1$. The plot assumes post breakthrough in all zones.

\subsection{Rate vs Cumulative Oil}

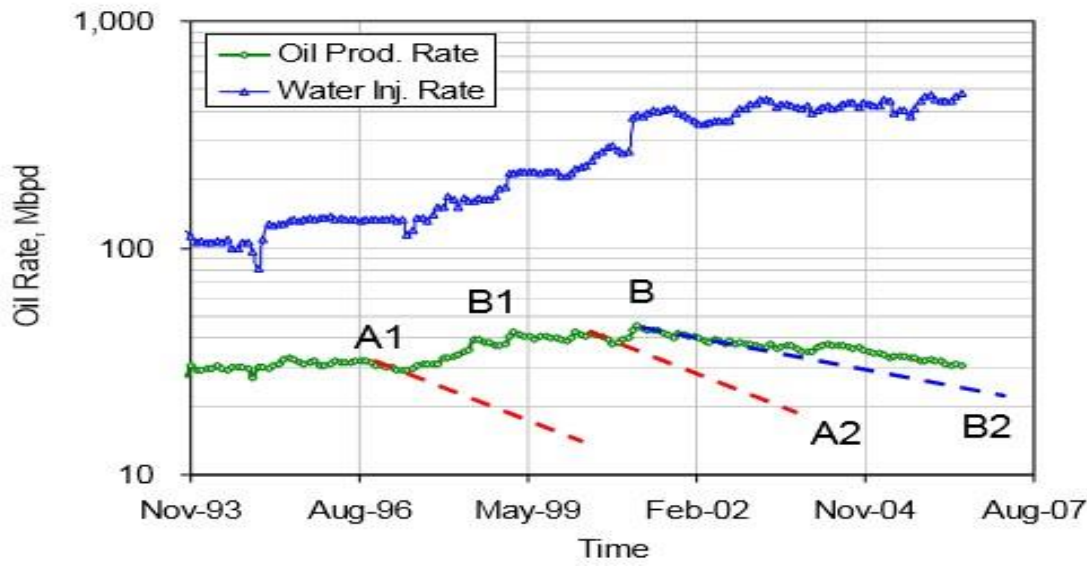

Graph 3. Rate vs Cum. Oil

The graph above shows the relationship between water injection and oil production rate. A zone is said to have a good response to water flooding if an increase in the volume of water injection will make a decline in the trend of sloping oil production so that the reserves that can be taken are greater before reaching the economic limit. The graph above shows the relationship between water injection and oil production rate. A zone is said to have a good response to water flooding if an increase in the volume of water injection will make a decline in the trend of sloping oil production so that the reserves that can be taken are greater before reaching the economic limit.

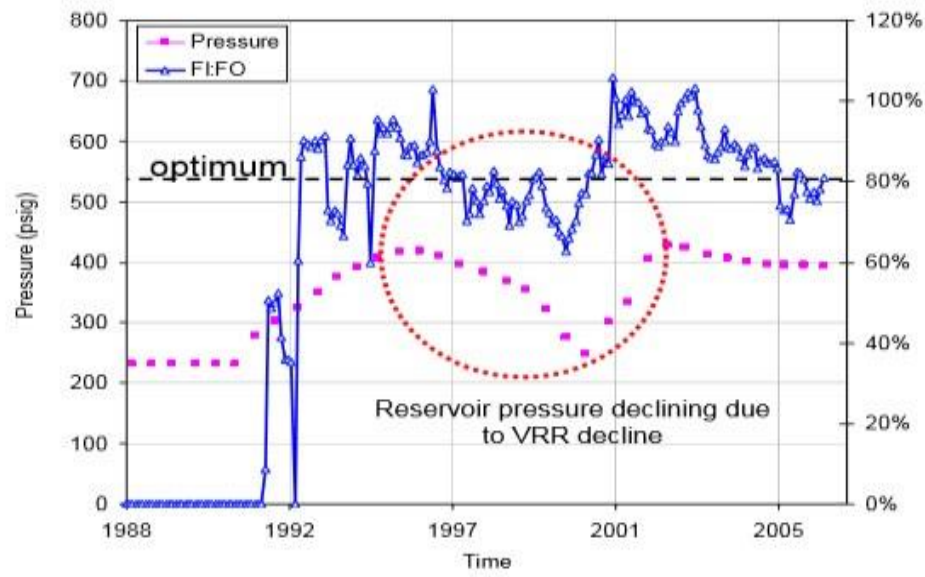

Graph 4. Pressure vs Time 


\subsection{Pressure vs Time}

In addition to sweeping the reserves that are still left in the reservoir, water flooding has a function as pressure maintenance. The response of a zone is said to be good if the water injection can maintain reservoir pressure at the desired pressure so that reservoir pressure does not drop dramatically due to the production of reservoir fluid to the surface.

\subsection{Oil Rate vs Oil Cumulative}

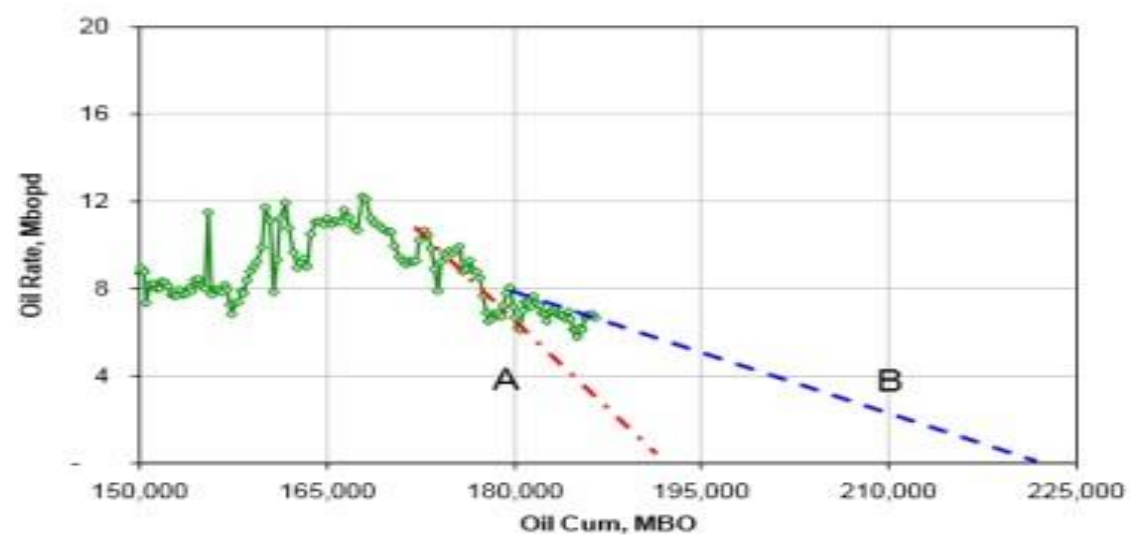

Graph 5. Oil Rate vs Cumulative Oil

The graph above shows that the decline rate is sloping from A (30\%) to B (19\%) by increasing the injection rate.

\subsection{Injector Well Hall Plot}

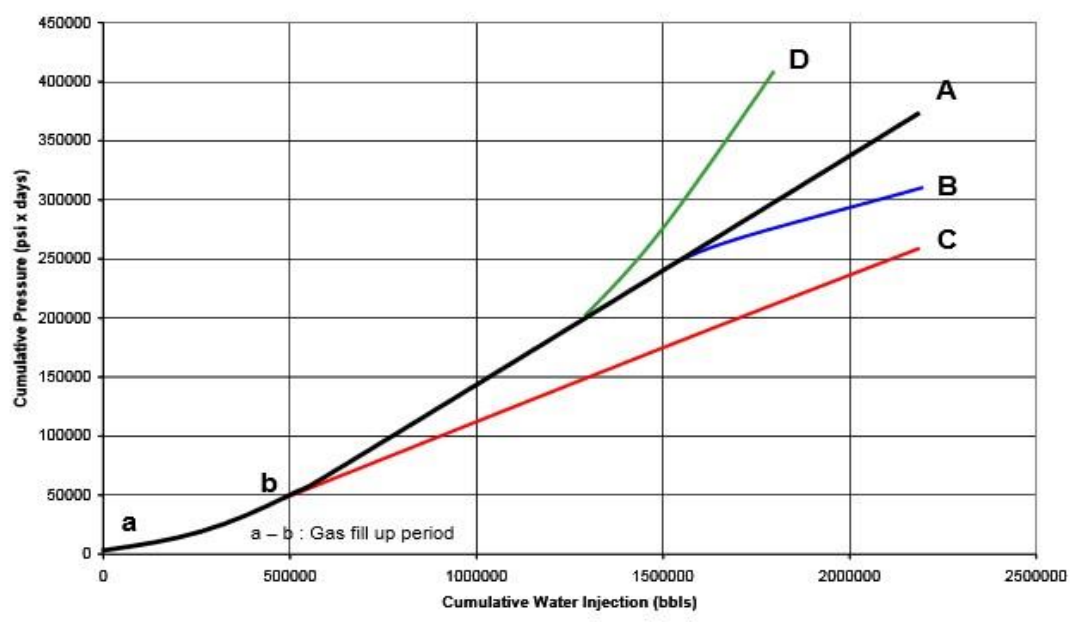

Graph 6. Injector Well Hall Plot

Hall plot is based on the plot between cumulative pressure vs. cumulative volume of water injection, where:

$\mathrm{A}=$ Normal injection

$\mathrm{B}=$ Stimulation around the wellbore (negative skin) or injection above fracture pressure

$\mathrm{C}=$ There is an indication of channeling or coming out of the injection zone

$\mathrm{D}=$ Plugging (positive skin) or poor water quality

\section{OVERVIEW FIELD X-MIN}

The X-Min Field is a field that produces light oil and is managed by the Asset Optimization SLO North PT. Chevron Pacific Indonesia. This field was discovered in 1959 and started to be produced in 1966. Currently, 100 wells have been drilled with 37 active wells from 43 production wells, active injector wells are 18 out of 19 , 
inactive wells 30, 4 wells have been plugged in, and there are 4 active wells that produce gas. The number of OOIPs in this field is $593 \mathrm{MMBO}$ with cumulative production reaching 283.7 MMBO and Recovery Factor reaching 47.7\%. In 2017 it was noted that the current production in December 2017 amounted to 5,374 BOPD / 121,264 BFPD or in other words the water cut reached 96.6\%. Meanwhile, the amount of injection used to optimize this field is 144,103 BWIPD. Reservoirs in this field have 4 reservoirs namely Res-1, Res-2, Res-3, and Res-4 wherein each reservoir there are several sands optimized using waterflood.

\section{WATERFLOOD PERFORMANCE ANALYSIS FOR EACH SAND FIELD X-MIN}

Analysis per sand requires data such as Pore Volume Injected (PVI), Recovery Factor (RF), Oil Rate, Injection Rate, Cumulative Oil, Pressure, VRR, and Time.

From the data that has been given then processed and made a plot based on the Diagnostic Plot to then analyze the response of each sand to water flooding. From this analysis, recommendations were made on what to do with the sand.

There were 8 sand analyzed, including Sand Ashique, Sand Bajubaru, Sand Cemangad, Sand Emakpintar, Sand Fantamantap, Sand Gulungulung, Sand Harikita, and Sand Istimewa.

Here is a brief analysis of one of the sands, namely Sand Gulungulung based on the Diagnostic Plot.

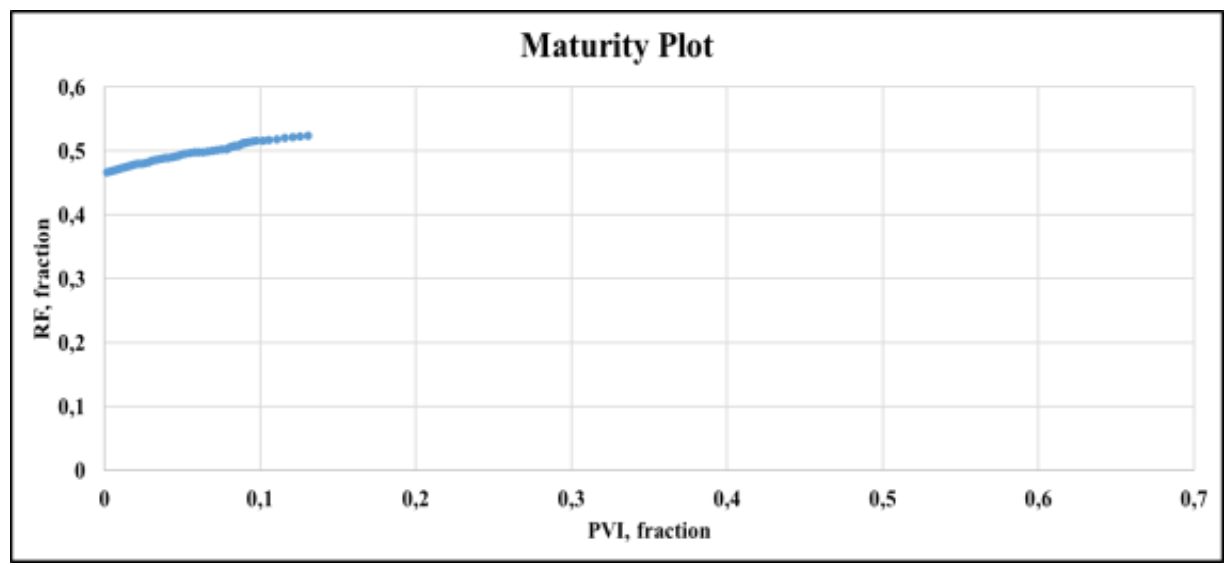

Graph 7. Example of Maturity Plot Sand Gulung-Gulung

Maturity plot formed from data in Pasir Gulung-gulung shows a fairly high increase in RF with a fairly low PVI. This can be an indication that the response of Pasir Gulungulung to flood water is quite good. However, it should also be noted that other diagnostic plots are needed to confirm whether this is indeed the effect of water flooding or is still in the primary depletion stage even after an injection has been carried out.

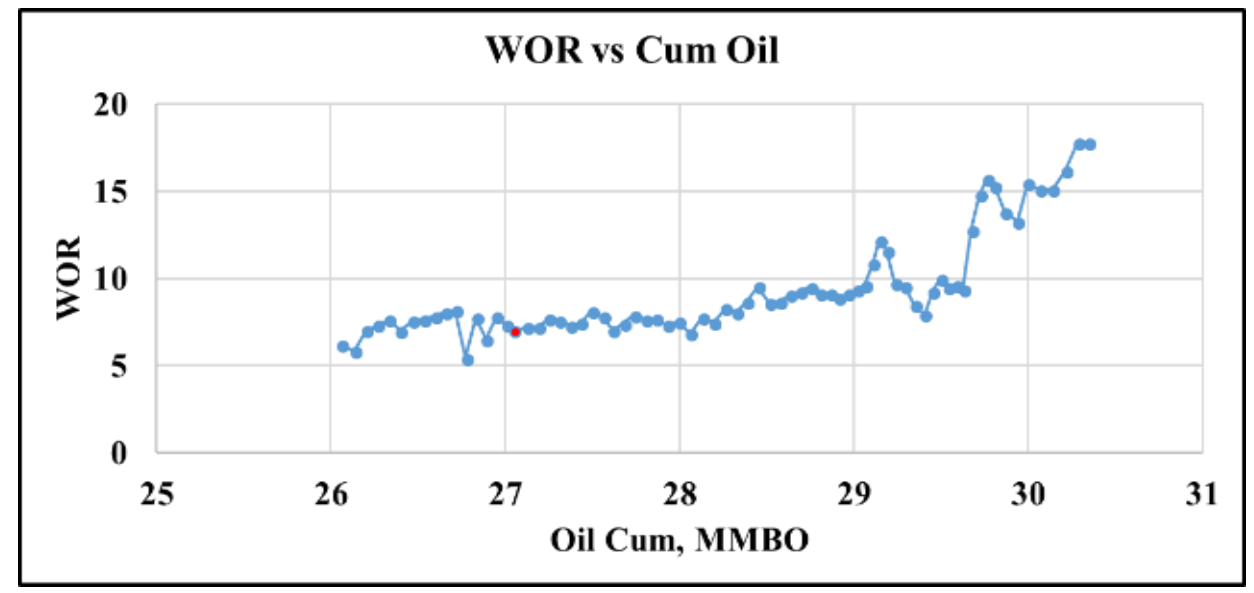

Graph 8. Example of WOR vs Cum. Oil Sand Gulung-gulung

Based on graph 1.8. WOR trends did not improve after the waterflood, which meant that water injection had not had a visible impact on WOR trends. WOR even increases at the end of the period, which could indicate a premature water breakthrough at the producer close to the injector. 


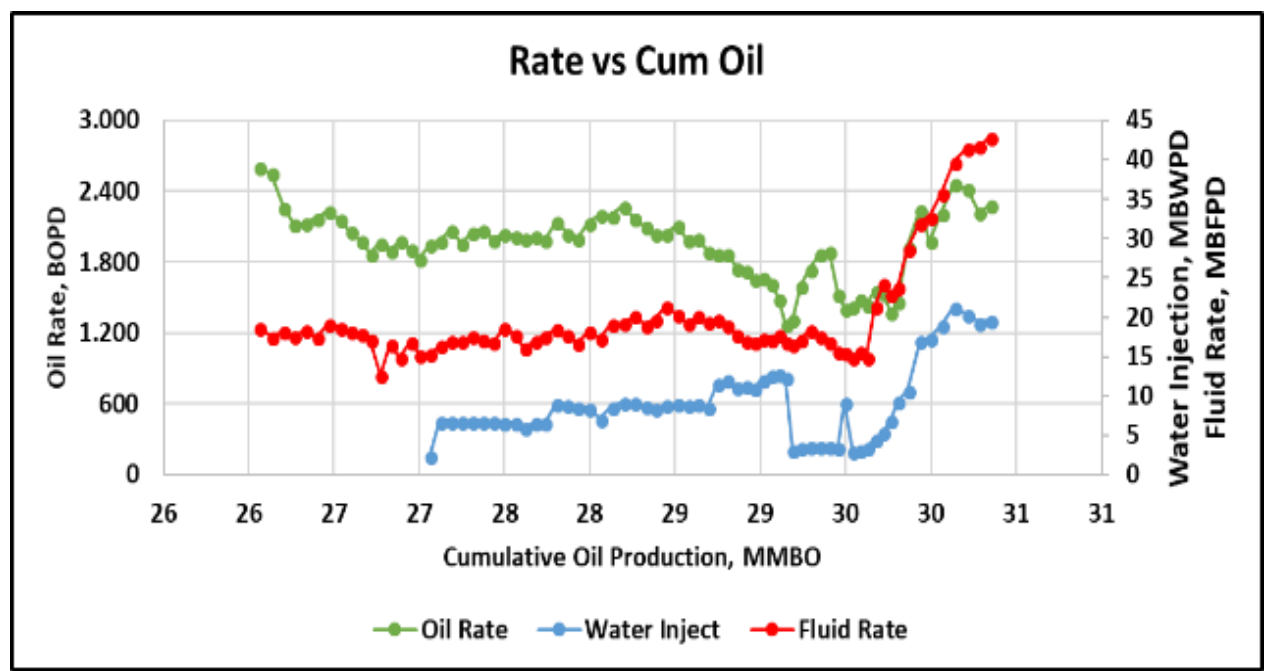

Graph 9. Rate vs Cum. Oil Sand Gulung-gulung

Rate vs. Cum Oil graphs on Sand Gulungulung increasingly show that water injection has not had a significant impact on oil sweeping in the reservoir. The increase in the oil rate is more due to an increase in fluid rate. The response of good waterflood will increase the oil rate and the fluid rate will remain constant.

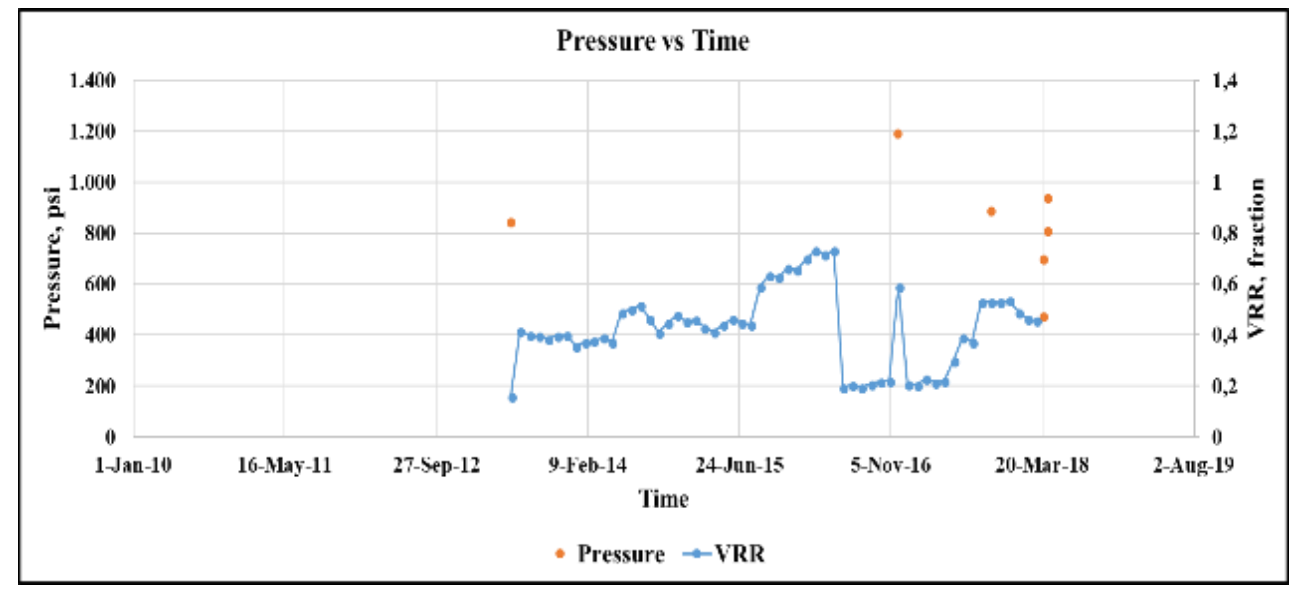

Graph 10. Pressure vs Time Sand Gulung-gulung

For pressure maintenance, water injection is sufficient to have an impact in the form of an increase in reservoir pressure. Whereas the VRR ratio is maintained to maintain the reservoir pressure at the desired pressure. 


\section{Water and Oil}

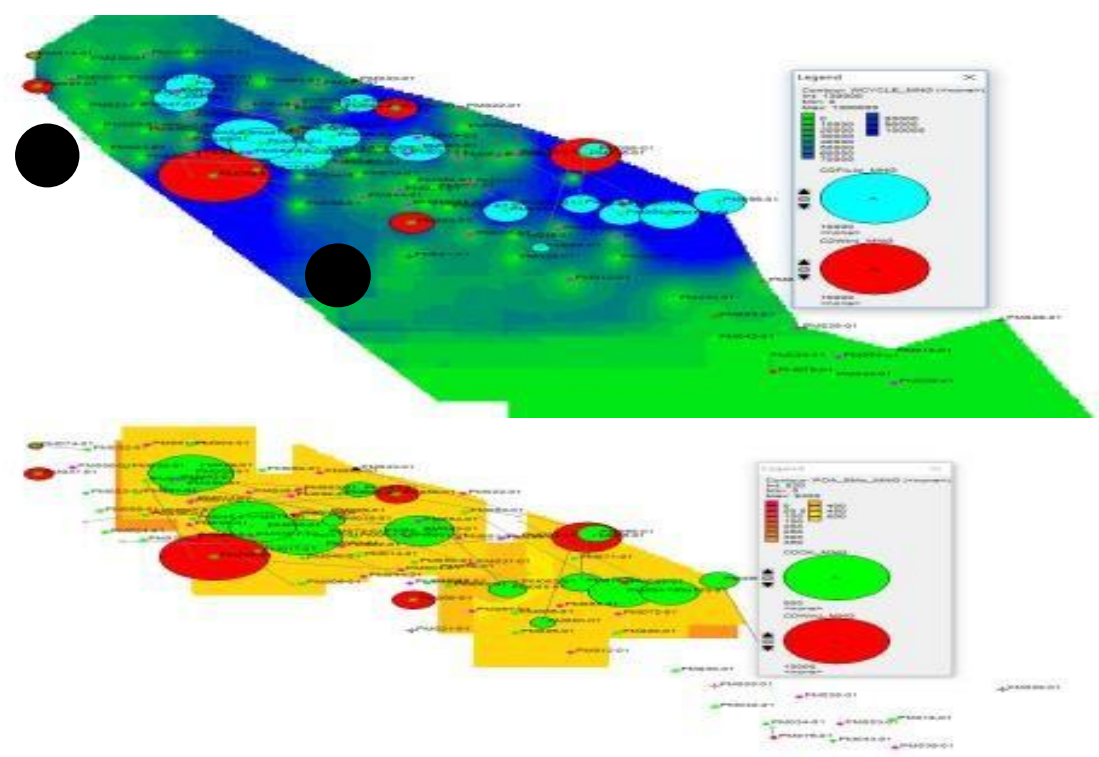

Figure 1. Water and Oil Attribute Map Sand Gulung-gulung

The map above shows the location of the injector and producer. The size of the circle shows the size of the injection rate and the production rate. Based on the bubble map above, that Sand Gulung-gulung has a lot of producers with large rates but has not been supported with a good injection rate. So the addition of the injector is needed to get the sweeping function or as pressure maintenance.

\section{RESULT}

1. The addition of PVI to the increase in RF is best shown in Gulung-gulung sand.

2. Opportunities to optimize, especially on Ash Assyria because the RF obtained only reached 0.175. However, at this time Sand Asyique can still be produced in a primary manner.

3. There is an error and need to calculate the allocation of factors in Sand Harikita.

4. Based on diagnostic plots, sand in Field-X-Min can be divided into three characteristics related to the response to waterflood.

5. Sand that has not yet responded and is still in the primary depletion stage $\rightarrow$ Sand Asyique and Sand Gulung-gulung.

6. Sand with poor response to waterflood $\rightarrow$ Sand Cemangad.

7. Sand with a good response to waterflood $\rightarrow$ Bajubaru, Emakpintar, Fantamantap, Harikita, and Special.

8. Some sand, as in Bajubaru, Emakpintar, and Gulung-gulung indicated breakthrough, is possible from wells that are close to the injector, marked by the WOR trend suddenly rising quite high.

9. Need more complete data to further analyze the performance of each sand during a waterflood

\section{RECOMMENDATION}

- Close the producer indicated premature water breakthrough

- Make additions or subtractions, both injectors and producers based on the response of each sand to water flooding. 


\begin{tabular}{|c|c|c|c|c|}
\hline SAND & INJECTOR & PRODUCER & $\begin{array}{c}\text { INJECTION } \\
\text { RATE }\end{array}$ & $\begin{array}{c}\text { PRODUCTION } \\
\text { RATE }\end{array}$ \\
\hline ASYIQUE & TAMBAH & TAMBAH & NAIKKAN & NAIKKAN \\
\hline BAJUBARU & TETAP & TAMBAH & JAGA & NAIKKAN \\
\hline CEMANGAD & TETAP & TAMBAH & JAGA & NAIKKAN \\
\hline EMAKPINTAR & TETAP & TAMBAH & JAGA & NAIKKAN \\
\hline FANTAMANTAP & TAMBAH & TAMBAH & NAIKKAN & NAIKKAN \\
\hline GULUNG- & TAMBAH & TAMBAH & NAIKKAN & NAIKKAN \\
\hline GULUNG & TAMBAH & TAMBAH & NAIKKAN & NAIKKAN \\
\hline HARIKITA & TETAP & TAMBAH & JAGA & NAIKKAN \\
\hline ISTIMEWA & \multicolumn{2}{|l}{} & & \\
\hline
\end{tabular}

Table 1. Recommendation of each sand

\section{REFERENCE}

Donaldson, Erle C., et. all. 1985. "Enhanced Oil Recovery". Elsevier Science Publishing Company INC. New York. Chapter 8 halaman $251-273$.

Gonzales, Laureano., et. all. 2014. "Use of Reservoir Simulation to Estimate Drainage Area and Recovery Factor of an In-Situ Combustion Project in a Complex Water-Drive Reservoir". SPE Heavy Oil Confrence. Canada.

Kristanto, Dedy., Rukmana, Dadang. 2011. “Teknik Reservoir Teori dan Aplikasi”. Percetakan Pohon Cahaya. Yogyakarta. Bab VIII halaman 232. Bab VIII halaman 252 - 265. Bab XI halaman 408 - 412.

Liu, Feliong. 2012. “Optimizing Water Injection Rates For A Waterflooding Field”. SPE Annual Technical Conference and Exhibition. Texas, USA.

Mulyawan, Ruby. 2005. "Technical and Practical Approaches to Improve Recovert of Mature/Marginal Field Minas North West Segment Case Study”. Simposium Nasional IATMI. ITB, Bandung.

Permadi P. Putra E., dan Butarbutar M. E. 2000. "A Method to Estimate the Drainage Area of a Horizontal Well". SPE Asia Pacific Oil and Gas Conference and Exhibition. Australia.

Rukmana, Dadang. 2013. “Simulasi Reservoir”. Dinas Pengembangan Lapangan SKK Migas. Indonesia.

Tarek, Ahmed. 2012. "Reservoir Engineering Handbook”. Gulf Publishing Company, Houston, Texas. Chapter 11 halaman $745-764$.

Thakur, Ganesh C. 1994. "Integrated Petroleum Reservoir Management". Chapter 6. hal 103 - 105, Chapter 8 halaman $155-158$.

Thomas, C.E., et all. 1962. "Petroleum Engineering Handbook". Core Laboratories Inc. Houston, USA. Chapter 44 halaman 1 Willhite, G. Paul. "Waterflooding”. SPE Foundation. United States. Chapter 6 halaman 199 - 224 